\title{
CHALLENGES FOR THE DEVELOPMENT OF A BIOTIC LIGAND MODEL PREDICTING COPPER TOXICITY IN ESTUARIES AND SEAS
}

\author{
ANNA DE POLO†, MARK D SCRIMSHAW ${ }^{*}$ \\ $\dagger$ Institute for the Environment, Brunel University, Uxbridge, UB8 3PH, United Kingdom
}

\begin{abstract}
There is an on-going effort to develop a Biotic Ligand Model (BLM) that predicts copper toxicity in estuarine and marine environments. At present, the BLM accounts for the effects of water chemistry on copper speciation, but it does not consider the influence on the physiology of the organisms. We discuss how chemistry affects copper toxicity not only by controlling its speciation, but also by affecting the osmoregulatory physiology of the organism, which varies according to the salinity. In an attempt to understand the mechanisms of copper toxicity and predict the impacts, we explore the hypothesis that the common factor linking the main toxic effects of copper is the enzyme carbonic anhydrase (CA), since it is a copper target with multiple functions and salinity-dependant expression and activity. According to this hypothesis, the site of action of copper in marine fish may be not only the gill, but also the intestine, since in this tissue CA plays an important role in ion transport and water adsorption. Thus, the BLM of copper toxicity to marine fish should also consider the intestine as a biotic ligand. Finally, we underline the need to incorporate the osmotic gradient into the BLM calculations to account for the influence of physiology on copper toxicity.
\end{abstract}

Keywords: biotic ligand model, copper, carbonic anhydrase, osmotic gradient, salinity

* To whom correspondence may be addressed (mark.scrimshaw@brunel.ac.uk) 


\section{INTRODUCTION}

Historically, the environmental quality criteria/standards (Environmental Quality Standards, EQSs, in the EU and Water Quality Criteria, WQC, in the U.S.) for metals have been based on total, or total dissolved, metal concentrations, despite the fact that many physiological and toxicological studies have demonstrated that water chemistry affects both bioavailability and toxicity of metals to aquatic organisms [1-4]. The effect of water chemistry began to be incorporated into regulations from the 1970s onwards, when the European Agencies and the U.S. Environment Protection Agency (EPA) developed higher quality standards for metals in fresh waters than for those in marine waters [5]. The threshold values in freshwaters were also adjusted for hardness, in order to generate site-specific WQC/EQS [6]. This represented a breakthrough because, for the first time, the regulatory authorities acknowledged the relevance of water chemistry on metal bioavailability and toxicity, even though other critical water chemistry variables, e.g. dissolved organic matter (DOM), were still overlooked. A further step in accounting for bioavailability was represented by the implementation in the U.S. of the water effects ratio (WER) procedure [7], which accounted for the difference between the toxicity of the metal in laboratory water and its toxicity in the water at the site. The WER is determined by dividing the endpoint (i.e. LC50: the concentration that is lethal to the 50\% of the test organisms) obtained in the site water by the endpoint obtained in the laboratory diluted water. This procedure, although effective, implies a number of site specific tests and analyses, while the regulatory authorities have a need for easy-to-use tools to assess site-specific water quality standards for metals [8].

Speciation and toxicity models can respond to the need for ease of use because they incorporate the complexity of the environment into simplified systems based on specific assumptions. Their

\footnotetext{
* To whom correspondence may be addressed (mark.scrimshaw@brunel.ac.uk)
} 
value does not depend on their capability to reproduce reality in the most exhaustive way, but actually on their usefulness and effectiveness. Their theory, along with the calibration data on which they are founded, has to be robust enough to give realistic output data over a wide range of conditions. In this respect, one of the most relevant systems developed for the aquatic environment is the Biotic Ligand Model (BLM) [9], originally conceived to predict metal availability and toxicity to freshwater fish and daphnids $[10,11]$. The model is essentially composed of two parts, a "chemistry-based" part and a "physiology-based" part (Figure 1).

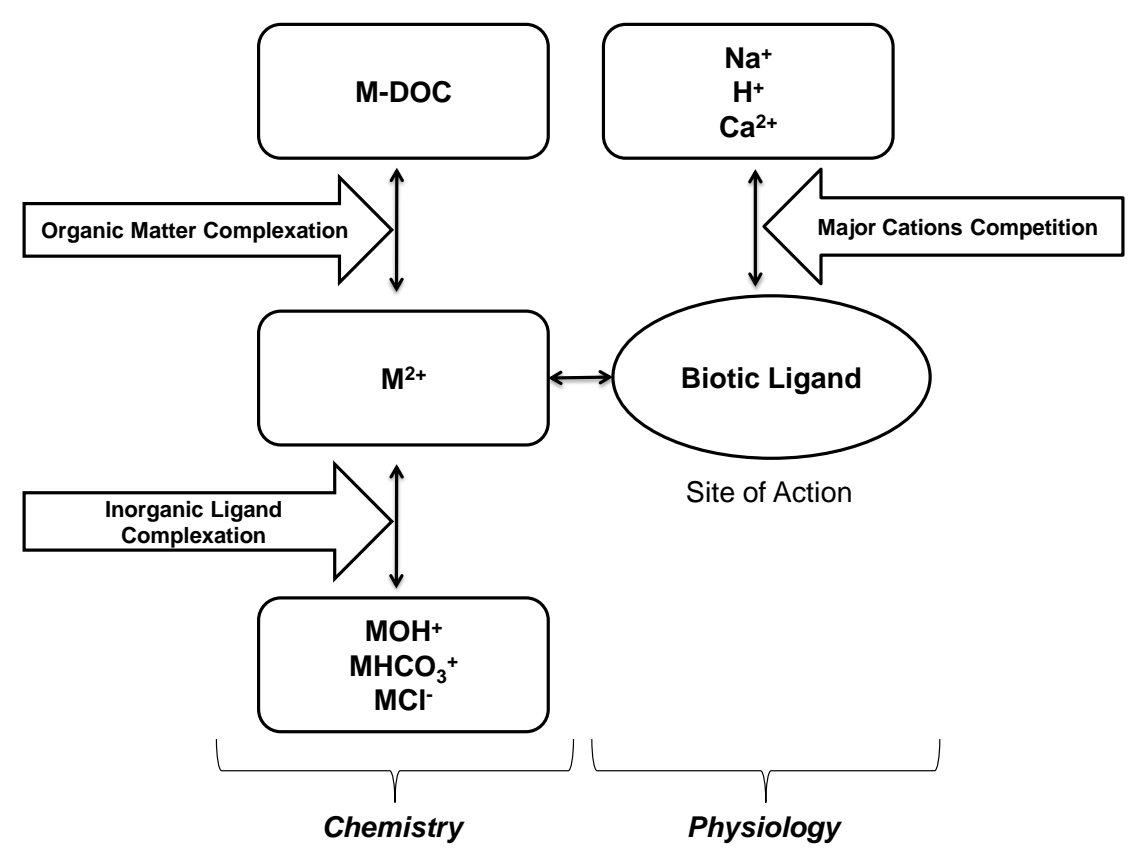

Figure 1 - Schematic diagram of the Biotic Ligand Model.

The first is represented by the chemical speciation computations, both inorganic and organic: the inorganic speciation is relatively simple and is performed by the Chemical Equilibria in Soils and Solution (CHESS) model [12], while the organic speciation is computed by the Windermere 
Humic Acid Model (WHAM), developed by Tipping and co-workers [13, 14]. Modelling the complexation of metal cations by organic matter is challenging, because of uncertainties regarding the characteristics of the ligands and their binding constants. The second part of the BLM accounts for the effect of the metal binding to the biotic ligand and it is based on the concept that toxicity effects occur when the metal-biotic ligand complex reaches a critical concentration.

The BLM has gained acceptance in the scientific and regulatory communities over the last decade, with the U.S. EPA publishing, in 2007, its Framework for Metal Risk Assessment [15], which introduced the BLM as a tool to derive criteria for protection of aquatic life. The BLM has successively been adopted by the Australian and New Zealand Environmental Protection Agencies as a tool for regulating metal concentrations in the aquatic environment [16] and it is in the process of being adopted by Environment Canada and the European Union. In 2008 the UK Environment Agency published a report on EQSs for trace metals in the aquatic environment [17], which recommended the use of BLM-type models to assess compliance with EQSs. In particular, they proposed a "field" BLM, the Toxicity Biotic Model (TBM), that may in the future be optimized with field data and possibly include the effect of metal mixtures, which is considered an outstanding issue that needs to be addressed. They also developed and presented a tiered assessment approach [18] that takes into account background metal concentrations. Through this approach it would be possible to prioritise sites where the concentration of a metal exceeds the EQS expressed in terms of total dissolved concentration, allowing focusing resources on sites at most risk.

In 2009 a European workshop discussed the incorporation of metal bioavailability into the regulatory framework [19] and concluded that the application of the BLM in estuarine and 
marine environments should be carefully evaluated. In the marine environment, work should be focused on the DOM variable, given the different characteristics of riverine, marine and estuarine organic matter, while in estuaries the complexity of the geochemical dynamics and the osmoregulatory responses of the estuarine organisms should be accounted for, otherwise the effectiveness of the model might be compromised.

The BLM framework is based on both water chemistry and physiology. The former factor greatly influences copper bioavailability and thus its toxicity: alkalinity, water hardness, $\mathrm{pH}$, DOM and salinity are all variables that affect copper speciation [1-4]. High salinity, in particular, has a protective effect against copper toxicity, since it reduces the availability of the metal as a consequence of both increased inorganic metal complexation and increased competition for binding sites by cations such as $\mathrm{Na}^{+}, \mathrm{Mg}^{2+}$ and $\mathrm{Ca}^{2+}[9,20]$. But in addition, salinity can also affect the physiology of aquatic organisms by influencing the mechanisms they adopt to maintain an osmotic balance and thus their responses to metal exposure [21, 22]. Copper toxicity can vary depending on osmoregulatory strategies adopted by the organisms: osmoregulators and osmoconformers display different patterns of sensitivity to copper, as well as differing physiological responses as salinity changes. The iso-osmotic point of the organism and, in general, the relative $\mathrm{Na}^{+}$gradient between the internal fluids and the external environment, particularly the electrochemical gradient across the gill epithelium, can affect the osmoregulatory strategy of the organism and consequently its sensitivity to the metal $[21,23]$. The BLM does account for the effects of water chemistry on metal speciation, but it does not explicitly consider the influence of water chemistry on the physiology of the organisms. For this reason, although both physiology and water chemistry are likely to be critical in determining copper toxicity, there is a need for research on the BLM to shift from the "chemistry-based side" to the "physiology- 
based side" of the model, so that understanding of the mechanism of toxicity may underpin predicting the effects of acute exposure. The aim of the present review is to discuss both these aspects, with particular regard to the effect of water chemistry on physiology, underlining the main issues that need to be addressed in future research, with a view to the development of a marine and estuarine version of the model.

\section{COPPER SPECIATION IN ESTUARINE AND COASTAL ENVIRONMENTS}

Many estuarine and coastal zones are areas of special scientific interest and their habitats are under some kind of protection, but they are also among the ecosystems at greatest risk from anthropogenic impact, because they are affected by many human activities, including shipping, urbanization and industrialization, which are leading to their degradation [24]. One of the main concerns about these environments is the presence of metals, particularly copper, since its usage as a biocide in antifouling painting coatings has largely increased after the banning of TBT [25]. A recent survey from UK harbours, marinas and estuaries has observed that only between 10 and $30 \%$ of total dissolved copper in these areas is present in the labile fractions (i.e. free copper ion and inorganically bound copper), which are believed to be the toxic forms, whereas most of the dissolved copper is present in the non-toxic form (i.e. organically bound copper) [26]. These results suggest that the use of total copper concentrations as an indicator of toxicity may lead to an overestimation of the environmental risk. For this reason, there are ongoing efforts to incorporate copper speciation in EQS/WQC and to develop a BLM model more suitable to estuarine and marine environments [26].

Even though the BLM has shown some potentiality in predicting copper toxicity to marine organisms, it still has some limitations. Considering only the chemistry-based side of the model, 
one of the main issues regards the metal complexation with organic matter, which is calculated using WHAM. This model has been developed and validated on data obtained at concentrations of metals and humic substance appropriate for freshwaters [13, 27]. However, in estuarine and marine waters the concentrations are generally lower. Organic matter in these environments is also likely to have different characteristics and in particular different complexation capacities, compared to fluvial material $[28,29]$. Thus, data on copper speciation and DOM concentrations and complexation capacity are necessary for the development of a marine version of the BLM. Furthermore, some studies have shown that the source of DOM has a significant effect on acute copper toxicity [29-33]. This effect, although not specifically taken into account by the BLM at present, may be accounted for by refining either the percentage of active humic acid (\%AHA) [34] or the DOM ligand density [30], which both affect organic matter complexation capacity in the model.

Since correct modelling of copper complexation by the organic matter appears to be critical in estuaries, where most of the metal is complexed by organic ligands [35], it may be worthwhile considering possible alternatives to WHAM, which however has been shown to be the most robust in predicting organic complexation with metals in estuaries [35]. Among the models that describe the interaction of organic matter with metals, two of them have been applied to estuaries with some success: the Stockholm Humic Model (SHM) [36] and the Nica-Donann Model [37], which is part of the Visual MINTEQ Model. The main difference between them regards the modelling of the binding sites of the organic matter: WHAM and SHM consider discrete binding sites on the organic matter surface, whereas the Nica-Donann model uses a bimodal, continuous distribution of binding affinity values for protons and metal ions. 
From a purely chemical perspective, an estuary represents a zone where seawater of high ionic strength is diluted by river water, resulting in a linear salinity gradient. The two main driving forces are the river and the tidal flows: the relative intensities of one or the other control the vertical stratification of the estuary and, ultimately, the mixing of river and sea water [38]. On the basis of their vertical mixing, estuaries can be classified into three categories: partly-mixed, well-mixed and salt-wedge. Even though this classification is often rather theoretical, it can still be useful in designing an experiment with the aim of predicting and modelling the fate and behaviour of a chemical contaminant, such as copper. In this context, dissolved metal species vary mainly as a function of salinity and, to a lesser extent, to $\mathrm{pH}$ and redox conditions. In an estuary, $\mathrm{pH}$ generally shows significant variation, which can produce a critical change in copper speciation. Model calculations have indicated that, in the absence of organic ligands, copper speciation is dominated by carbonate complexation [39], which has a strong influence on the concentration of $\mathrm{Cu}^{2+}$, as an increase in $\mathrm{pH}$ from 7.6 to 8.2 results in a 3 -fold reduction of the $\mathrm{Cu}^{2+}$ concentration [40].

In summary, the main issues that should be addressed in the development of a BLM for estuaries and sea are the interaction between copper and organic matter, with particular regard to the different DOM sources, and the effect of $\mathrm{pH}$ on copper speciation, considering the relevance of carbonate complexation at high salinity.

\section{EFFECTS OF SALINITY ON PHYSIOLOGICAL RESPONSES TO COPPER IN ESTUARIES AND SEA}

\section{Osmoregulatory strategies and copper toxicity in saltwater}


All freshwater (FW) organisms osmoregulate to maintain the internal salt concentration above that of the external environment. They do this by an active uptake of $\mathrm{Na}^{+}$, which can be inhibited by copper exposure [41], that may also affect the $\mathrm{Na}^{+}$leakage pathway [42]. As this is true for both fish and invertebrates, it is one reason why in freshwater the BLM is relatively successful in predicting acute copper toxicity in both groups of organisms, although the sensitivity to copper displayed by FW organisms varies of more than three orders of magnitude among different taxa [21]. On the other hand, saltwater (SW) organisms present a wider inter-taxa variability of osmoregulatory strategies. In particular, SW teleost fish (bony fish) are osmo- and ionoregulators, as they maintain extracellular ion concentrations much below that of the surrounding medium. For this reason they need to continuously intake seawater and excrete the excess salts to compensate for water loss due to the osmotic gradient and the diffusion of salts into their tissues [21]. Elasmobranch (cartilaginous) fish are iono-regulators and osmo-conformers, because they regulate the ion concentration at approximately $50 \%$ of that in the $\mathrm{SW}$, but they maintain the osmotic pressure of extracellular fluids similar to the surrounding medium by reabsorbing and retaining urea and other organic osmolytes in their tissues. This allows them to drink less seawater, as do teleosts, but they still face the problem of the diffusion of salts from the external SW, where the ion concentration is higher, into their body. They compensate for this by salt excretion in urine, by secretion from the rectal gland and by salt transfer at the gill epithelium [43]. Finally, most marine invertebrates are both iono- and osmoconformers, because their ionic composition and osmotic pressure are highly similar to those of the surrounding seawater [21]. Since it is known that acute copper toxicity is mainly a consequence of its effect on ion transport [44-48], it is plausible that differences in osmoregulatory strategies may result in differences in copper sensitivity among species and also, as the salinity changes, within the same species. If we 
assume that copper exerts its toxic effect by disrupting the maintenance of a net $\mathrm{Na}^{+}$gradient, we may hypothesize that osmoregulators would be more sensitive to copper than osmoconformers. As the available data do not support this expectation (see Grosell et al. [21] for a review), the hypothesis that copper acts as an osmoregulatory toxicant in seawater will be discussed.

In marine osmoconformers exposed to copper the principal cause of mortality appears to be either a disturbance in acid-base balance, related to impaired respiratory gas exchange, and/or an effect on ammonia excretion [49-52], although there is also evidence for copper toxicity via oxidative stress [53], DNA damage [54] and metabolic inhibition as a secondary effect of oxygen uptake inhibition [55]. In marine osmoregulators the studies regarding the effects of copper are equivocal. There is, however, a general agreement in recognizing impaired ion regulation as the main effect of copper exposure $[45-48,56]$, both in fish and invertebrates. Acute and chronic copper exposure of the gulf toadfish Opsanus beta induced an increase in plasma $\mathrm{Na}^{+}$and $\mathrm{Cl}^{-}$ concentrations, due to impaired osmoregulatory capacity both in the gill and in the intestine, resulting in fluid loss from muscle tissue [45]. These results are in accordance with previous studies on the seawater-adapted flounder Platichthys flesus and the rainbow trout Oncorhynchus mykiss $[57,58]$. However, some exceptions exist: in other studies on the killifish Fundulus heteroclitus and the cod Gadus morhua, disturbances in acid-base balance and ammonia excretion were the main observed effects $[23,59]$. In the experiments performed on the killifish, copper toxicity was studied across a range of salinities, from freshwater to seawater [23]. The hypothesis that copper would act via the same general mechanism regardless of salinity was tested, but the results did not confirm this. Indeed, in FW the expected mechanism of toxicity was observed; in particular a decrease in plasma $\mathrm{Na}^{+}$concentration occurred, caused by the copper-induced inhibition of the $\mathrm{Na}^{+} / \mathrm{K}^{+}$ATPase activity. However, in SW no effect was 
observed either on $\mathrm{Na}^{+}$homeostasis or on $\mathrm{Na}^{+} / \mathrm{K}^{+}$ATPase activity. The only parameter affected by copper exposure was ammonia excretion, which has also been reported to be affected by copper in other studies $[58,59]$.

Taken together, these observations not only demonstrate the complex pattern of physiological responses to copper, but also suggest that the main target of copper toxicity might be a common factor, which controls ion transport along with acid-base balance and nitrogenous waste excretion. If we assume this, we can try to give an overall explanation for the main reported effects of copper, both in osmoconformers and osmoregulators. In the former, acid-base and ammonia excretion disturbances seem to be the main causes of copper-induced mortality, since the maintenance of an osmoregulatory gradient is not an issue for this group of animals, while in osmoregulators the disturbance of ion transport is the main effect, as the maintenance of a $\mathrm{Na}^{+}$ gradient is critical for them, but acid-base balance and ammonia excretion are also affected, and in some cases are more sensitive endpoints [23] (Table 1).

Table 1. A summary of the effects of copper in osmoregulators and osmoconformers

\begin{tabular}{|c|c|c|}
\hline \multirow[t]{2}{*}{ Main effects } & \multicolumn{2}{|c|}{ Osmoregulatory strategies } \\
\hline & Osmoregulators & Osmoconformers \\
\hline $\begin{array}{l}\text { Acid-base balance disturbance, caused by impaired } \\
\text { gas-exchange }\end{array}$ & $\bullet$ & $\bullet$ \\
\hline $\begin{array}{l}\text { Increase in plasma ammonia concentration, caused by } \\
\text { impaired ammonia excretion }\end{array}$ & • & • \\
\hline Impaired intestine and/or branchial ion transport & $\bullet$ & \\
\hline Drinking rate disturbances & $\bullet$ & $\bullet$ \\
\hline
\end{tabular}




\section{Carbonic anhydrase enzyme: a copper target with multiple functions and a salinity-dependant}

\section{expression}

A common denominator of the previously described mechanisms is the enzyme carbonic anhydrase (CA). In fact, this enzyme can bind copper, which in turn can inhibit its activity, as it has been shown in crustaceans exposed both in vivo and in vitro to this metal [60, 61], although this mechanism of action in fish has been confirmed only by in vitro experiments [62], but so far not in vivo [23]. This enzyme is present in a range of tissues, including gill and intestine epithelia, and is involved, directly or indirectly, in several physiological processes, including gas-exchange, acid-base balance, $\mathrm{Na}^{+}$and $\mathrm{Cl}^{-}$transport and ammonia/ammonium excretion [63, 64], which are all reported to be affected by copper exposure. The main function of the enzyme is to facilitate the conversion of carbon dioxide and water to bicarbonates and protons [65]. In the gill of FW fish, the protons produced by the hydration of the carbon dioxide are involved in $\mathrm{Na}^{+}$transport at the apical membrane, while the bicarbonates are exchanged for chloride. The inhibition of CA, besides influencing these mechanisms, can also affect ammonia excretion, by reducing the diffusive trapping mechanism [66-68]. Hence the multiple functions of CA make it a candidate as the common factor that links together ion transport as well as acid-base balance and nitrogenous waste excretion and thus offer a possible explanation of the complex pattern of physiological responses to copper exposure. This hypothesis can be supported by giving further consideration to marine osmoregulators, with some distinctions between fish and crustaceans. In marine fish there are two sites of ion transport, the gill and the intestine, that are both relevant in the maintenance of the osmotic balance. In contrast to FW fish, ion transport in SW fish is not believed to be directly associated with CA in the gill [69], but it is in the intestine, which is responsible for taking up water to compensate for the diffusive loss of water to the concentrated 
external environment $[69,70]$. Water absorption is driven by the uptake of $\mathrm{Na}^{+}$and $\mathrm{Cl}^{-}$, which are then excreted at the gill. Ions are moved actively through the intestinal epithelium and water follows passively along the generated osmotic gradient, from the intestinal lumen into the blood. The presence of copper (and also silver [71-73], which has a similar toxic effect) in seawater can reduce drinking rates, depending on the exposure time, and interferes with the intestinal uptake of water [46] through the inhibition of the active ion uptake processes that drive water flux by osmosis. The driving force for the movement of ions across the intestinal epithelium is provided by the enzyme $\mathrm{Na}^{+} / \mathrm{K}^{+}$ATPase, but, to date, the inhibition of its activity by metal exposure has not been demonstrated to be responsible for the impaired uptake processes in the intestine of marine fish, so it is plausible that one or several other proteins involved in ion transport are more sensitive targets. One of them is the enzyme CA, which has been shown to play a key role in osmoregulation [74]. It has been demonstrated that both gene expression and enzymatic activity of CA can be modulated by salinity changes, similarly to the enzyme $\mathrm{Na}^{+} / \mathrm{K}^{+}$ATPase, and that their response is tissue-specific, with significant differences between gills and intestine. Considering the gill, the salinity-dependence of CA expression and activity has been demonstrated in several studies, but this pattern still needs to be fully elucidated, since some discrepancies exist among species. In killifish an increase in CA gene expression was observed after transfer from intermediate salinity to freshwater [75]; in the coho salmon Oncorhynchus kisutch and in the Mozambique tilapia Oreochromis mossambicus, CA activity increased with increasing salinity $[76,77]$, while the flounders kept at different salinities did not show any significant differences in CA activity [78].

Considering the intestine, CA expression and activity increased 2- to 4-fold in killifish [23] after transfer to seawater. In the rainbow trout a salinity change induced a response that involved two 
isoforms of the enzyme CA: the cytosolic CA (CAc) and the extracellular isoform membranebound CA type IV (CAIV), localized at the apical region of the intestine epithelium [79]. The former usually displays the majority of the CA activity in the intestinal epithelium and provides the cellular substrate for the $\mathrm{Cl}^{-} / \mathrm{HCO}_{3}{ }^{-}$anion exchanger on the apical membrane [80]. The latter contributes to the deposition of $\mathrm{CaCO}_{3}$ in the intestinal lumen, which reduces the osmotic concentration of the intestinal fluid and thus facilitates ion transport and water absorption through the epithelium [81]. An osmotic stress, such as caused by an abrupt transfer from freshwater to $65 \%$ saltwater, induced in the rainbow trout a transient increase of the mRNA expression and of the enzymatic activity both of CAc and membrane-bound CAIV [79]. A recent study on CA expression and activity, both in the intestine and in the gills of the gulf toadfish following transfer to salinity of $60 \mathrm{ppt}$, demonstrated that the CAc was important for tolerance to hypersalinity [74]. What emerges from these studies is that the enzyme CA plays a key role in osmoregulation and the modulation of its activity and expression appears to be a response to osmotic stress. If we hypothesize that CA is the main copper target in SW, and that in fish it displays its osmoregulatory functions mainly in the intestine, then we might assume that the copper target in SW is not (or not only) in the gill, but (also) in the intestine, and so consider the copper speciation and bioavailability in this medium. It has been observed that copper becomes less bioavailable as it moves along the intestine of the gulf toadfish: this may be due to the fact that the absorption/excretion mechanisms at the intestinal epithelium progressively modify the chemical composition of the intestinal fluid and thus the speciation and availability of copper [46].

Metabolically, marine crustaceans are less complex than fish, since the only tissue where the enzyme CA may be involved in copper sensitive functions is the gill. However, although marine 
crustaceans are invertebrates, which are generally osmoconformers, several species can shift from osmoconformity to osmoregulation below a critical salinity, typically around $25 \mathrm{ppt}[82$, 83]. The enzyme CA has been characterized as one of the central components of ion uptake in the branchial epithelium of crustaceans [83], since its expression is salinity sensitive and its inhibition has been linked to the disruption of ion transport and regulation [84]. The increase in CA activity in response to low salinity appears to be a central feature of the transition from osmoconformity to osmoregulation and this is believed to be a common adaptive characteristic of all euryhaline marine crustaceans capable of osmotic- and iono-regulation [63, 85]. If copper exposure affects CA activity, it may interfere with their ability to respond to osmotic stress and thus result in osmoregulatory imbalance.

Conceptually, from the modelling perspective, the validation of the hypothesis presented here would mean that the biotic ligand in marine fish is not only the gill, but also the intestine (as suggested also for silver $[74[72,73])$, and the relationship between toxic effect and metal accumulation at the binding site is modulated by salinity and in particular by the osmotic gradient.

Branchial permeability and mucus secretion: an alternative explanation of copper effects on gill functionality

Another explanation of the toxic effects of copper is a general alteration of the epithelial function of the gill. Since most of the processes that have been reported to be affected by copper toxicity are associated with ion regulation at the gill, a generalized mode of action has been hypothesized, possibly caused by mucus secretion [56]. Mucus is thought to act as a buffer, preventing the metal from interacting with the site of toxicity, but, if a thick layer of mucus is 
produced, it may increase the diffusive distance at the gill surface and thus affect branchial processes by reducing branchial permeability. However, most studies on the effects of copper exposure reported an increase, not a decrease, in branchial permeability, due to a displacement of $\mathrm{Ca}^{2+}$ at the gill surface, which controls the passive diffusion of $\mathrm{Na}^{+}, \mathrm{Cl}^{-}$and also $\mathrm{Mg}^{2+}$, all ions that demonstrated an increase in plasma concentrations after copper exposure $[45,58]$.

\section{$\mathrm{Na}^{+} / \mathrm{K}^{+}$ATPase activity: why not a target in saltwater?}

An issue that may need to be elucidated is why the $\mathrm{Na}^{+} / \mathrm{K}^{+}$ATPase activity is one of the targets of copper in FW [86], while it is reported to be unaffected in SW [87]. Since this enzyme is central to ion transport by the gills of both freshwater and marine fish, it may therefore be expected to respond similarly to copper in the two environments. An explanation to these apparently puzzling observations can be found in a study conducted on the gill of the SWadapted flounder [57], to which copper was applied in both in vitro and in vivo experiments. The application of copper to gill homogenates during the in vitro experiments caused a marked reduction in $\mathrm{Na}^{+} / \mathrm{K}^{+}$ATPase activity, but the in vivo experiments showed that copper exposure induced an increase in the number of $\mathrm{Na}^{+} / \mathrm{K}^{+}$ATPase units in the gill. This increase counterbalances the reduced activity of each $\mathrm{Na}^{+} / \mathrm{K}^{+}$ATPase site and thus resulted in an overall unchanged $\mathrm{Na}^{+} / \mathrm{K}^{+}$ATPase activity in the gill tissue, as reported in most studies on marine fish gill physiology. Furthermore, the increase of $\mathrm{Na}^{+} / \mathrm{K}^{+}$ATPase units is controlled by the production of cortisol [88], a hormone responsible for osmoregulatory balance in SW, the concentration of which is enhanced by copper exposure. Another effect of higher levels of cortisol is the enhancement of protein catabolism [88], which increases ammonia production and thus plasma ammonia concentration, a reported effect of exposure to copper. A further explanation of the apparent insensitivity of the $\mathrm{Na}^{+} / \mathrm{K}^{+}$ATPase to copper at high salinity is 
provided by the observation that rapid salinity change can induce the expression of different isoforms of the enzyme [89]. It is plausible that different isoforms may display differential sensitivity to copper [46].

\section{How salinity changes affect copper toxicity? The relevance of the osmotic gradient}

With the development of a BLM for marine and transitional waters in mind, the previous considerations imply that an estuarine/marine version of the BLM should give more relevance to the physiology, as it has been shown to be important in marine and transitional environments. At present, species differences in sensitivity are dealt with through adjustments of the stability constants characterizing the metal/gill interaction. This may be sufficient in FW, but in SW it cannot explain the variation in sensitivity to copper shown by SW and estuarine organisms. The physiological mechanisms lying at the base of the osmotic regulation system are more various and variable in marine organisms than in freshwater ones and thus result in a large inter-species variation in copper sensitivity and an intra-species variation in copper sensitivity when salinity changes [21]. The second point is particularly relevant if we consider estuaries, transitional waters or other environments characterized by fluctuating salinities.

Estuarine invertebrates display a wide range of osmoregulatory strategies. In general, at their isoosmotic point they are osmoconformers. Above it, they are still generally osmoconformers, although a few (particularly decapods crustaceans) are able to osmoregulate [90]. Below the isoosmotic point they weakly osmoregulate up to a certain salinity level, after which they start strongly osmo- and iono- regulating $[83,91]$. A few estuarine invertebrates are osmo- and iono-

regulators in the full tolerance range $[92,93]$. A good example of the transition from osmotic and ion conformity to regulation is given by the euryhaline green crab Carcinus maenas, which is an osmoconformer in full strength seawater but, at a critical salinity of $26 \mathrm{ppt}$, starts to actively 
uptake ions across the gill. The activation of the mechanisms of ion transport is correlated with an 8-fold induction of the enzyme CA. The role of CA in ion transport and regulation in this species is confirmed by the observation that the ability of green crabs to regulate their hemolymph osmotic and ion concentrations is disrupted when branchial CA activity is inhibited [84]. A similar mechanism was also observed in the blue crab Callinectes sapidus [94]. If copper exposure affects CA activity, which is a key feature of the acclimation of euryhaline organisms to salinity changes, it might be deduced that copper exposure can theoretically affect the ability of euryhaline species to respond to osmotic stress.

Reviewing eight studies on the influence of salinity to acute copper toxicity, Grosell et al. [21] pointed out that none of the studies showed a linear increase in tolerance with increasing salinity, as competitive interactions among cations would have suggested, and the displayed tolerance variations were not fully explained on the basis of copper speciation. A non-linear trend of LC50 values related to salinity gradient has also been reported in a recent study of copper toxicity to the estuarine copepod Eurytemora affinis [20]. Here the lowest toxicity was observed around the iso-osmotic point of the organism, a fact also seen in the work by Grosell et al. [21]. The trend of copper toxicity related to salinity gradient displayed in this study (Figure 2) suggests that the physiology of the organism was the driving factor influencing toxicity and thus supports the observation that euryhaline species are more tolerant to metal exposure at iso-osmotic salinities, due to minimization of osmotic stress [95]. By comparing measured and predicted values (calculated using the main equation of the BLM, as modified by De Schampheleare et al. [96]), Figure 2 also demonstrates that at present BLM predictions are inaccurate across such a wide salinity range (from 0 to $35 \mathrm{ppt}$ ), although, as indicated by the good agreement at high salinities, it may accurately predict toxicity in some limited situations [97]. Since copper disrupts the 


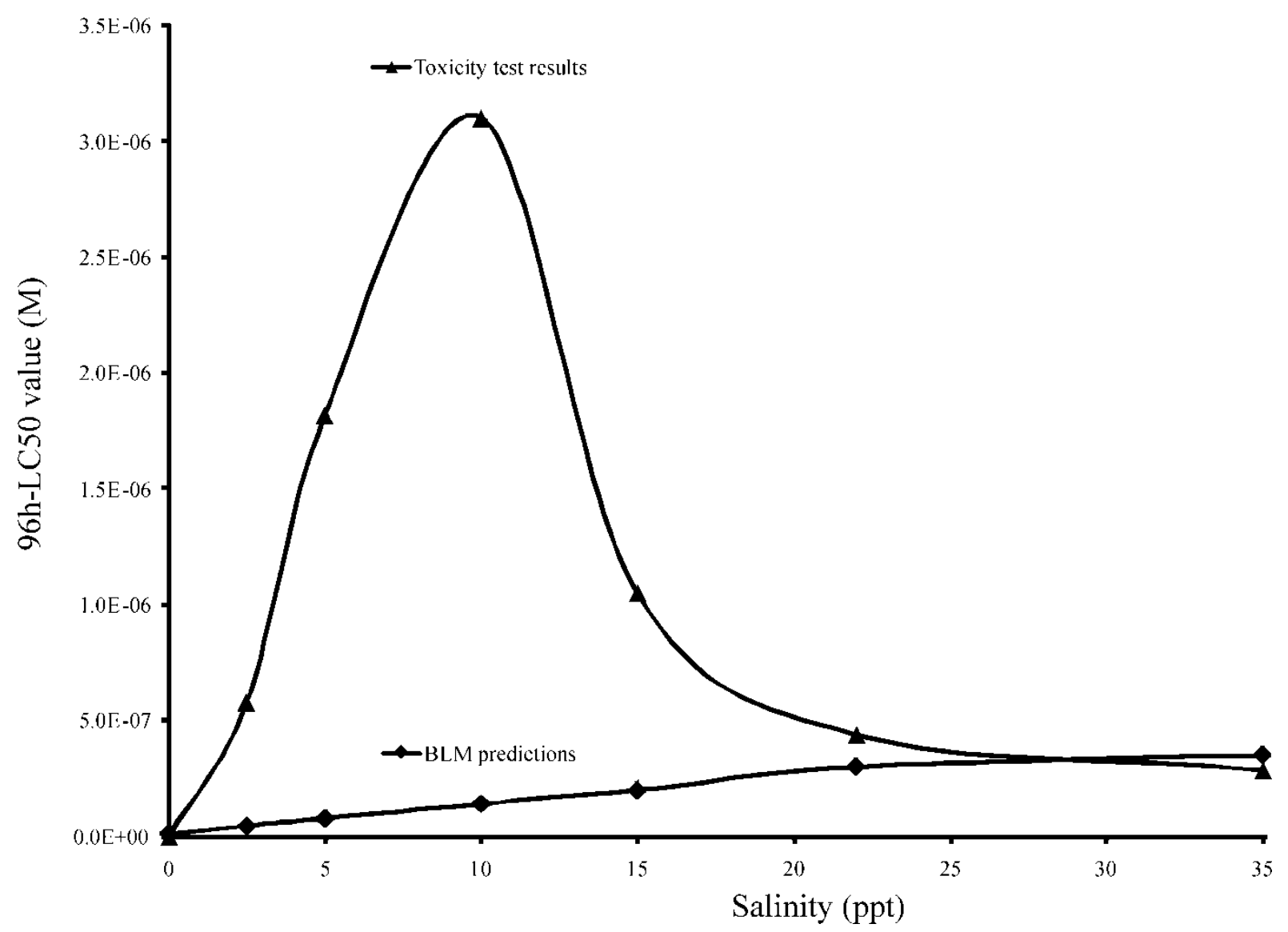

Figure 2- Comparison of acute $\mathrm{Cu}$ toxicity to juvenile killifish, Fundulus heteroclitus, as a function of ambient salinity, along with BLM predictions. Data from Grosell et al. [21], and vales predicted by the BLM equation as modified by De Schamphelaere et al, (2002) [96]. Values are expressed as free metal ion activity.

ability to sustain the osmotic gradient between the internal fluids and the external medium, the greater the gradient, the higher is the toxic effect. Including a parameter which accounts for the equilibrium potential across the gill epithelium $\left(\mathrm{E}_{\mathrm{p}}\right)$ may thus reduce the bias between the predictions of the model and the observed toxicity, since the $E_{p}$ undergoes a wide variation with salinity (Figure 3).

Water and ions (including metals) are exchanged between the internal fluids and the external environment at different rates, in relation to the osmotic gradient and, ultimately, to the salinity 
$[21,98]$. This means that metal uptake and toxicity (assuming a direct relationship between metal accumulation at the biotic ligand, uptake rate and toxic response) is modulated by the osmotic gradient. But the mechanism is even more complex, since the mode of action of copper (i.e. the biotic ligand in the "BLM language") changes according to the osmoregulatory physiology, which varies with salinity. Thus the relationship between copper exposure and toxic response is influenced by salinity through a "double" interaction: on the one hand copper inhibits the ability of the organism to respond to an osmotic stress, by interfering with its osmotic mechanisms (i.e. $\mathrm{CA}$ ), but, at the same time, a salinity variation produces an increase in copper uptake, due to a general increase in ion uptake rate, as well as, in some cases, a change in the copper biotic ligand. At present, this complex relationship is clearly overlooked by the BLM, which assumes that the toxic response is directly related to the amount of copper bioavailable and to its affinity for the binding sites, regardless of the water chemistry.

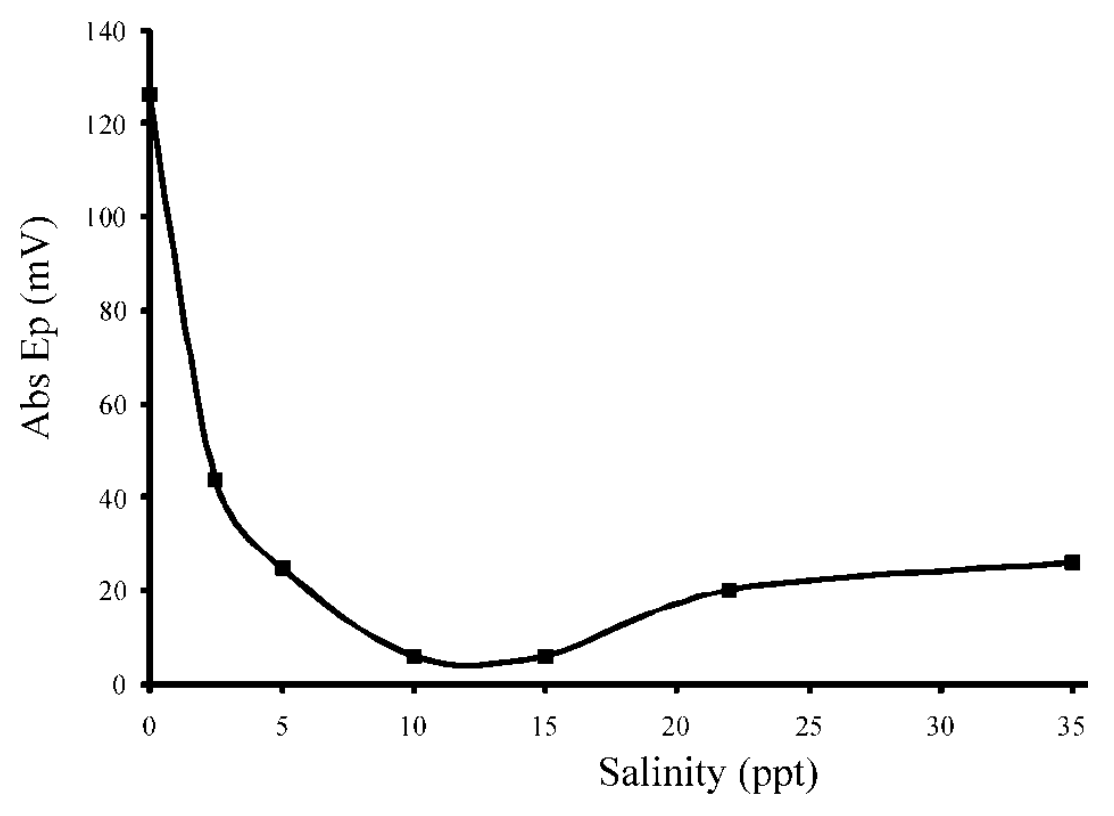

Figure 3 - Absolute Equilibrium Potential $\left(\mathrm{E}_{\mathrm{p}}\right)$ at different salinities, data from Grosell et al. [21]. 
Conceptually, the challenge is to introduce the effect of water chemistry (i.e. salinity) on the physiology-based part of the model. In other words, we hypothesize that, at varying salinities (i.e. in an estuary), the relationship between the $[\mathrm{Cu}] \mathrm{EC} 50$ and the fraction of binding sites that need to be occupied by the metal to observe a toxic effect in $50 \%$ of the test organisms $\left(\mathrm{f}_{\mathrm{CuBL}}^{50 \%}\right)$ is not linear and constant, but variable and modulated by the osmotic gradient.

\section{CONCLUSIONS}

In conclusion, considering the chemistry-based part of the model, it is necessary to improve the ability of the BLM to describe the interaction between copper and organic matter: further investigations should be addressed at the different sources of DOM in estuaries and sea, with particular regards to their stability constants. Copper speciation studies in estuaries should also take into account the effect of $\mathrm{pH}$, since it displays a significant change in this environment and it influences the carbonates, which are thought to dominate inorganic copper speciation in estuarine and sea waters.

As for the physiology-based part of the model, this presents the main issues of interest. We suggest that in estuaries and sea the water chemistry affects copper toxicity not only by controlling its speciation, but also by affecting the osmoregulatory physiology of the organism, which in turn varies according to the salinity. We present the hypothesis that the common factor that links together the main observed effects of copper, both in osmoregulator and in osmoconformer organisms, is the CA enzyme, given its multiple functions and its salinitydependent expression and activity. According to this hypothesis, we also suggest that the site of action of copper in marine fish is not only the gill, but also the intestine, since this is where CA plays a role in ion transport and water adsorption. Thus, the BLM model of copper toxicity to 
marine fish may also consider the intestine as a biotic ligand. There is thus a need to incorporate the osmotic gradient, and possibly the osmoregulatory strategy of organisms, into BLM calculations, in order to use a mechanistic understanding to predict the impacts of acute copper exposure in a wide range of salinities.

\section{ACKNOWLEDGMENTS}

Anna De Polo is grateful to Brunel University for the award of an Isambard Scholarship.

\section{References}

1. Pagenkopf GK. 1983. Gill surface interaction model for trace-metal toxicity to fish: role of complexation, pH, and water hardness. Environ Sci Technol 17:342-347.

2. Erickson RJ, Benoit DA, Mattson VR, Nelson HP, Leonard EN. 1996. The effects of water chemistry on the toxicity of copper to fathead minnows. Environ Toxicol Chem 15:181-193.

3. Welsh PG, Lipton J, Chapman GA, Podrabsky TL. 2000. Relative importance of calcium and magnesium in hardness-based modification of copper toxicity. Environ Toxicol Chem 19:1624-1631.

4. Meador JP. 1991. The interaction of $\mathrm{pH}$, dissolved organic carbon, and total copper in the determination of ionic copper and toxicity. Aquat Toxicol 19:13-31.

5. Alabaster JS, Lyoid R. 1980. Water Quality Criteria for freshwater fish. Butterworth Scientific, London.

6. USEPA. 1986. Quality Criteria for Water-1986. EPA 440/5-86-001.

7. USEPA. 1994. Interim guidance on determination and use of Water Effects Ratio (WERs) for metals. EPA/823/B-94/001. 
8. Reiley MC. 2007. Science, policy, and trends of metals risk assesment at EPA: how understanding metal bioavailability has changed metal risk assesment at US EPA. Aquat Toxicol 84:292-298.

9. Paquin PR, Gorsuch JW, Apte S, Batley SA, Bowels KC, Campbell PGC, Delos CG, Di Toro DM, Dwyer RY, Galvez F, Gensemer RW, Goss GG, Hogstrand C, Janssen CR, McGeer JC, Naddy RB, Playle RC, Santore RC, Schneider U, Stubblefield WA, Wood CM, Wu KB. 2002. The Biotic Ligand Model - a historical overview. Comp Biochem Physiol C 133:3-35. 10. Di Toro MD, Allen HE, Bergman HL, Meyer JS, Paquin PR, Santore RC. 2001. Biotic Ligand Model of the acute toxicity of metals. 1. Technical basis. Environ Toxicol Chem 20:23832396.

11. Santore RC, Di Toro DM, Paquin PR, Allen HE, Meyer JS. 2001. Biotic Ligand Model of the acute toxicity of metals. 2. Application to acute toxicity in freshwater fish and Daphnia. Environ Toxicol Chem 20:2397-2402.

12. Santore RC, Driscoll CT. 1995. The CHESS model for calculating chemical equilibria in soils and solution. In Loeppert R, Schwab AP, Goldberg S, eds, Chemical Equilibrium and reaction Models, SSSA Special Pubblication $42 \mathrm{ed}$, The Soil Society of America, American Society of Agronomy, Madison, WI, pp 357-375.

13. Tipping E, Hurley M. 1992. A unifying model of cation binding by humic sustances. Geochim Cosmochim Ac 27:520-529.

14. Tipping E. 1994. WHAM--A chemical equilibrium model and computer code for waters, sediments and solils incorporating a discrete site/electrostatic model of ion-binding by humic substances. Comput Geosci 20:973-1023.

15. USEPA. 2007. Framework for metal risk assessment. EPA 120/R-07/001. 
16. [ANZECC/ARMCANZ] Australian and New Zealand Environment and Conservation Council/Agriculture and Resource Management Council of Australia and New Zealand. 2000. Australian and New Zeland Guidelines for fresh and marine water quality. Canberra, Australia. 17. Bass JAB, Blust R, Clarke RT, Corbin TA, Davison W, De Schamphelaere KAC, Janssen CR, Kalis EJJ, Kelly MG, Kneebone NT, Lawlor AJ, Lofts S, Temminghoff EJM, Thacker SA, Tipping E, Vincent CD, Warnken KW, Zhang H. 2008. Environmental Quality Standards for trace metals in the aquatic environment. SC030194. Science Report. Environment Agency, Bristol.

18. Comber SDW, Merrington G, Sturdy L, Delbeke K, van Assache F. 2008. Copper and zinc water quality standards under the EU Water Framework Directive: the use of a tiered approach to estimate the level of failure. Sci Total Environ 403:12-22.

19. TuTech Innovation GmbH. 2009. European Workshop on Metals in the Environment. Hamburg University of Technology.

20. Hall LW, Anderson RD, Lewis BL, Arnold WR. 2008. The influence of salinity and dissolved organic carbon on the toxicity of copper to the estuarine copepod, Eurytemora affinis. Arch Environ Contam Toxicol 54:44-56.

21. Grosell M, Blanchard J, Brix KV, Gerdes R. 2007. Physiology is pivotal for interactions between salinity and acute copper toxicity to fish and invertebrates. Aquat Toxicol 84:162-172. 22. Martins De Martinez Gaspar C, Barcarolli IF, de Menezes EJ, Giacomin MM, Wood CM, Bianchini A. 2011. Acute toxicity, accumulation and tissue distribution of copper in the blue crab Callinectes sapidus acclimated to different salinities: In vivo and in vitro studies. Aquat Toxicol 101:88-99. 
23. Blanchard J, Grosell M. 2006. Copper toxicity across salinities from freshwater to seawater in the euryhaline fish Fundulus heteroclitus: Is copper an ionoregulatory toxicant in high salinities? Aquat Toxicol 80:131-139.

24. Lotze HK, Lenihan HS, Bourque BJ, Bradbury RH, Cooke RG, Kay MC, Kidwell SM, Kirby MX, Peterson CH, Jackson JBC. 2006. Depletion, degradation, and recovery potential of estuaries and coastal seas. Science 312:1806-1809.

25. Brooks S, Waldock M. 2009. Copper biocides in marine environment. In Arai T, Harino H, Ohji M, Langston WJ, eds, Ecotoxicology of antifouling biocides, Vol 3. Springer, Japan, pp 413-428.

26. Jones B, Bolam T. 2007. Copper speciation survey from UK marinas, harbours and estuaries. Mar Pollut Bull 54:1127-1138.

27. Tipping E. 1993. Modeling the competition between alkaline-earth cations and trace-metal species for binding by humic substances. Environ Sci Technol 3:520-529.

28. Middelburg JJ, Herman PMJ. 2007. Organic matter processing in tidal estuaries. Mar Chem 106:127-147.

29. Ryan AC, Van Genderen EJ, Tomasso JR, Klaine SJ. 2004. Influence of natural organic matter source on copper toxicity to larval fathead minnows (Pimephales promelas): Implications for the Biotic Ligand Model. Environ Toxicol Chem 23:1567-1574.

30. Ryan AC, Tomasso JR, Klaine SJ. 2009. Influence of pH, hardness, dissolved organic carbon concentration, and dissolved organic matter source on the acute toxicity of copper to Daphnia magna in soft waters: Implications for the biotic ligand model. Environ Toxicol Chem 28:1663-1670. 
31. Al-Reasi H, Wood CM, Smith DS. 2011. Physicochemical and spectroscopic properties of natural organic matter (NOM) from various sources and implications for ameliorative effects on metal toxicity to aquatic biota. Aquat Toxicol 103:179-190.

32. DePalma SGS, Arnold WR, McGeer JC, Dixon DG, Smith DS. 2011. Variability in dissolved organic matter fluorescence and reduced sulfur concentration in coastal marine and estuarine environments. Appl Geochem 26:394-404.

33. Depalma SGS, Arnold WR, McGeer JC, Dixon DG, Smith DS. 2011. Effects of dissolved organic matter and reduced sulphur on copper bioavailability in coastal marine environments. Ecotoxicol Environ Saf 74:230-237.

34. De Schamphelaere KAC, Vasconcelos FM, Tack FMG, Allen HE, Janssen CR. 2004. Effect of dissolved organic matter source on acute copper toxicity to Daphnia magna. Environ Toxicol Chem 23:1248-1255.

35. Tipping E, Lofts S, Lawlor AJ. 1998. Modelling the chemical speciation of trace metals in the surface waters of the Humber system. Sci Total Environ 210-211:63-77.

36. Gustafsson JP. 2001. Modeling the acid-base properties and metal complexation of humic substances with the Stockholm Humic Model. J Colloid Interf Sci 244:102-112.

37. Benedetti MF, Milne CJ, kinniburgh DG, van Riemsdijk WH, Koopal LK. 1995. Metal ion binding to humic substances: application of the non-ideal competitive adsorption model. Environ Sci Technol 29:446-457.

38. Millward GE. 1995. Processes affecting trace elements speciation in estuaries. Analyst 120:609-614.

39. Turner DR, Whitfield M, Dickson AG. 1981. The equilibrium speciation of dissolved components in freshwater and seawater at $25 \mathrm{C}$ at $1 \mathrm{~atm}$. Geochim Cosmochim Acta 45:855-882. 
40. Culberson CH. 1981. Direct potentiomentry. In Whitfield M, Jagner D, eds, Marine Electrochemistry, J Wiley and Sons, Chichester, pp 187-261.

41. Grosell M, Wood CM. 2002. Copper uptake across rainbow trout gills: mechanisms of apical entry. J Exp Biol 205:1179-1188.

42. Evans DH. 1987. The fish gill: sute of action and model for toxici effects of environmental pollutants. Environ Heatlth Perspect 71:47-58.

43. Hammerschlag N. 2006. Osmoregulation in elasmobranchs: a review for fish biologists, behaviourists and ecologists. Mar Freshw Behav Phy 39:209-228.

44. Grosell M, Nielsen C, Bianchini A. 2002. Sodium turnover rate determines sensitivity to acute copper and silver exposure in freshwater animals. Comp Biochem Physiol C 133:287-303. 45. Grosell M, McDonald MD, Wood CM, Walsh PJ. 2004a. Effects of prolonged copper exposure in the marine gulf toadfish (Opsanus beta): I. Hydromineral balance and plasma nitrogenous waste products. Aquat Toxicol 68:249-262.

46. Grosell M, McDonald MD, Walsh PJ., Wood CM. 2004b. Effects of prolonged copper exposure in the marine gulf toadfish (Opsanus beta). II. Drinking rate, copper accumulation and $\mathrm{Na}^{+} / \mathrm{K}^{+}$-ATPase activity in osmoregulatory tissues. Aquat Toxicol 68:263-275.

47. Laurén D, McDonald D. 1985. Effects of copper on branchial ionoregulation in the rainbow trout, Salmo gairdneri (Richardson). J Comp Physiol B 155:635-644.

48. Pinho GLL, Bianchini A. 2010. Acute copper toxicity in the euryhaline copepod Acartia tonsa: implications for the development of an estuarine and marine Biotic Ligand Model.

Environ Toxicol Chem 29:1834-1840. 
49. Boitel F, Truchot JP. 1988. Acid-base equilibrium and ion concentrations in the crab Carcinus maenas exposed to sublethal and lethal concentrations of copper ions. Arch Int Physiol Biochim Biophys 96:A415-A415.

50. Boithel F, Truchot JP. 1989. Effects of sublethal and lethal copper levels on hemolymph acid-base balance and ion concentration in the shore crab Carcinus maenas kept in undiluited sea-water. Mar Biol 103:495-501.

51. Boithel F, Truchot JP. 1990. Comparative study of the effects of copper on hemolymph ion concentration and acid-base balance in shore crab Carcinus maenas acclimated to fullstrength or diluite seawater. Comp Biochem Physiol C 95:307-312.

52. Bielmyer GK, Brix KW, Capo TR, Grosell M. 2005. The effects of metals on embryolarval and adult life stages of the sea urchin, Diadema antillarum. Aquat Toxicol 74:254-263. 53. Main WPL, Ross C, Bielmyer GK. 2010. Copper accumulation and oxidative stress in the sea anemone, Aiptasia pallida, after waterborne copper exposure. Comp Biochem Physiol C $151: 216-221$.

54. Raimundo J, Costa PM, Vale C, Costa ML, Moura I. 2010. DNA damage and metal accumulation in four tissues of feral Octopus vulgaris from two coastal areas in Portugal. Ecotoxicol Environ Saf 73:1543-1547.

55. Viant MR, Walton JH, TenBrook PL, Tjeerdema RS. 2002. Sublethal actions of copper in abalone (Haliotis rufescens) as characterized by in vivo 31P NMR. Aquat Toxicol 57:139-151. 56. Lee JA, Marsden ID, Glover CN. 2010. The influence of salinity on copper accumulation and its toxic effects in estuarine animals with differing osmoregulatory strategies. Aquat Toxicol 99:65-72. 
57. Stagg RM, Shuttleworth TJ. 1982. The effects of copper on ionic regulation by the gills of the seawater-adapted flounder (Platichthys flesus L.). J Comp Physiol B 149:83-90.

58. Wilson RW, Taylor EW. 1993. Differential responses to copper in rainbow trout (Oncorhynchus mykiss) acclimated to sea water and brackish water. J Comp Physiol B 163:239246.

59. Larsen BK, Pörtner HO, Jensen FB. 1997. Extra- and intracellular acid-base balance and ionic regulation in cod (Gadus morhua) during combined and isolated exposures to hypercapnia and copper. Mar Biol 128:337-346.

60. Skaggs HS., Henry RP. 2002. Inhibition of carbonic anhydrase in the gills of two euryhaline crabs, Callinectes sapidus and Carcinus maenas, by heavy metals. Comp Biochem Physiol C 133:605-612.

61. Vitale AM, Monserrat JM, Castilho P, Rodriguez EM. 1999. Inhibitory effects of cadmium on carbonic anhydrase activity and ion regulation of the estuarine crab Chasmagnathus granulata (Decapoda, Grapsidae). Comp Biochem Physiol C C122:121-129.

62. Soyut H, Beydemir Ş, Hisar O. 2008. Effects of some metals on carbonic anhydrase from brains of rainbow trout. Biol Trace Elem Res 123:179-190.

63. Henry RP. 1984. The role of carbonic anhydrase in blood ion and acid-base regulation. Am Zool 24:241-253.

64. Henry RP. 1988. Multiple functions of carbonic anhydrase in the crustacean gill. J Exp Zool 248:19-24.

65. Perry SF. 1986. Carbon dyoxide excretion in fishes. Can J Physiol 64:565-572.

66. Randall DJ WP. 1989. The interaction between carbon dyoxide and ammonia excretion and water pH in fish. Can J Zool 67:2936-2942. 
67. Wright PA, Randall DJ, Perry SF. 1989. Fish gill water boundary layer: a site of linkage between carbon dyoxide and ammonia excretion. J Comp Physiol 158:627-635.

68. Wilson RW, Wright PA, Munger S, Wood CM. 1994. Ammonia excretion in rainbow trout Oncorhynchus mykiss: the importance of the gill boundary layer acidification: lack of evidence for $\mathrm{Na}^{+} / \mathrm{H}^{+}$exchange. J Exp Biol 191:37-58.

69. Marshall WS, Grosell M. 2005. Ion transport, osmoregulation and acid-base balance. In Claiborne JB, ed, Physiology of Fishes, CRC Press, Boca Raton, pp 264-283.

70. Loretz CA. 1995. Electrophysiology of ion transport in the teleost intestinal cells. Cellular and molecular approaches to fish ion regulation. In Wood CM, Shuttleworth TJ, eds, Fish Physiology, Vol 14. pp 25-56.

71. Wood CM, Playle RC, Hogstrand C. 1999. Physiology and modeling of mechanisms of silver uptake and toxicity in fish. Environ Toxicol Chem 18:71-83.

72. Webb NA, Wood CM. 2000. Bioaccumulation and distribution of silver in four marine teleosts and two marine elasmobranchs: influence of exposure duration, concentration, and salinity. Aquat Toxicol 49:111-129.

73. Webb NA, Shaw JR, Morgan J, Hogstrand C, Wood CM. 2001. Acute and chronic physiological effects of silver exposure in three marine teleosts. Aquat Toxicol 49:111-129.

74. Sattin G, Mager EM, Beltramini M, Grosell M. 2010. Cytosolic carbonic anhydrase in the Gulf toadfish is important for tolerance to hypersalinity. Comp Biochem Physiol A 156:169-175.

75. Scott GR, Claiborne JB, Edwards SL, Schulte PM, Wood CM. 2005. Gene expression after freshwater transfer in gills and opercular epithelia of killifish: insight into divergent mechanisms of ion transport. J Exp Biol 208:2719-2729. 
76. Zbanyszek R, Smith LS. 1984. Changes in carbonic anhydrase activity in coho salmon smolts resulting from physical training and transfer into seawater. Comp Biochem Physiol A 79:229-233.

77. Kultz D, Bastrop R SD. 1992. Mitochondria-rich (MR) cells and the activities of $\mathrm{Na}^{+} / \mathrm{K}^{+}-$ ATPase and carbonic anhydrase in the gill and opercular epithelium of Orechromis mossambicus adapted to various salinities. Comp Biochem Physiol 102B:293-301.

78. Mashiter K, Morgan MR. 1975. Carbonic anhydrase levels in the tissues of flounders adapted to sea water and fresh water. Comp Biochem Physiol A 1:713-717.

79. Grosell M, Gilmour KM, Perry SF. 2007. Intestinal carbonic anhydrase, bicarbonate, and proton carriers play a role in the acclimation of rainbow trout to seawater. Am J Physiol Regul Integr Comp Physiol 293:2099-2111.

80. Grosell M, Wood CM, Wilson RW, Bury NR HC, Rankin JC, Jensen FB. 2005.

Bicarbonate secretion plays a role in chloride and water absorption of the European flounder intestine. Am J Physiol Regul Integr Comp Physiol 288:R936-R946.

81. Wilson RW, Wilson JM GM. 2002. Intestinal bicarbonate secretion by marine teleost fishwhy and how? Biochim Biophys Acta 1566:182-193.

82. Towle DW, Rushton ME, Heidysch D. 1997. Sodium-proton antiporter in the euryhaline crab Carcinus maenas: molecular cloning, expression and distribution. J Exp Biol 200:10031014.

83. Henry RP. 2001. Environmentally mediated carbonic anhydrase induction in the gill of euryhaline crustaceans. J Exp Biol 204:991-1002. 
84. Henry RP, Gehnrich S, Weihrauch D, Towle DW. 2003. Salinity-mediated carbonic anhydrase induction in the gills of the euyhaline green crab Carcinus maenas. Comp Biochem Physiol A 136:243-258.

85. Piller SC, Henry RP, Dieller JR, Kreuse DW. 1995. A comparison of the gill physiology of two euryhaline crab species Callinectes sapidus and Callinectes similis: energy production, transport-related enzymes and osmoregulation as a function of acclimation salinity. $J$ Exp Biol 198:344-358.

86. Laurén DJ, McDonald DG. 1987b. Acclimation to copper by rainbow trout, Salmo gairdneri: biochemistry. Can J Fish Aquat Sci 44:105-111.

87. Grosell M, McDonald MD, Walsh PJ, Wood CM. 2004. Effects of prolonged copper exposure in the marine gulf toadfish (Opsanus beta) II: copper accumulation, drinking rate and Na+/K+-ATPase activity in osmoregulatory tissues. Aquat Toxicol 68:263-275.

88. De Boeck G, Vlaeminck A, Balm PHM, Lock RAC, De Wachter B, Blust R. 2000. Morphological and metabolic changes in common carp, Cyprinus carpio, during short-term copper exposure: interactions between $\mathrm{Cu}^{2+}$ and plasma cortisol elevation. Environ Toxicol Chem 20:374-381.

89. Richards JG, Semple JW, Shulte PM. 2003. Pattern of $\mathrm{Na}^{+} / \mathrm{K}^{-}$ATPase isoform expression in rainbow trout (Oncorhynchus mykiss). Integr Comp Biol 42:1300.

90. Spaargaren DH. 1972. Osmoregulation in the prawns Palaemon serratus and Lysmata seticaudata from the Bay of Naples. Neth J Sea Res 5:416-436.

91. Smith RI. 1970. Chloride regulation at low salinity by Nereis diversicolor (Anellida, Polychaeta). 1. Uptake and exchange of chloride. J Exp Biol 53:75-84. 
92. Skaer HB. 1974a. The water balance of a serpulid polychaete, Mercierella enigmatica (Fauvel): I. Osmotic concentration and volume regulation. J Exp Biol 60:321-330.

93. Skaer HB. 1974b. The water balance of a serpulid polychaete, Mercierella enigmatica (Fauvel): II. Ion concentration. J Exp Biol 60:331-338.

94. Henry RP, Watts SA. 2001. Early carbonic anhydrase induction in the gills of the blue crab, Callinectes sapidus, during low salinity acclimation is indipendent of ornithine decarboxylase activity. J Exp Zool 289:350-350.

95. Sprague JB. 1985. Factors that modify toxicity. In Rand GM PS, ed, Fundamentals of aquatic toxicology, Hemisphere Publishing Company, Washington DC, pp 124-163.

96. De Schampheleare KAC, Heijerick DG, Janssen CR. 2002. Refinement and field validation of a Biotic Ligand Model predicting acute copper toxicity to Daphnia magna. Comp Biochem Physiol C 133:243-258.

97. Arnold WR, Santore RC, Cotsifas JS. 2005. Predicting copper toxicity in estuarine and marine waters using the Biotic Ligand Model. Mar Pollut Bull 50:1634-1640.

98. Wildgust MA, Jones MB. 1998. Salinity change and the toxicity of the free cadmium ion $\left[\mathrm{Cd}^{2+}{ }_{(\mathrm{aq})}\right]$ to Neomysis integer (Crustacea: Mysidacea). Aquat Toxicol 41:187-192. 


\section{List of Figures}

Figure 2 - Scheme of the Biotic Ligand Model

Figure 2- Acute $\mathrm{Cu}$ toxicity to juvenile killifish, Fundulus heteroclitus, as a function of ambient salinity. The triangles represents the 96h LC50s values obtained by acute toxicity tests (data from Grosell et al, 2007), while the diamonds (dash line) are the values predicted by the basic BLM equation (as modified by De Schamphelaere et al, 2002 [96]). Both the values are expressed as free metal ion activity.

Figure 3 - Absolute Equilibrium Potential $\left(\mathrm{E}_{\mathrm{p}}\right)$ at different salinities (data from Grosell et al., 2007 [21]). 